\title{
PENGARUH DISIPLIN KERJA TERHADAP KINERJA GURU MTS SE- KOTA BANDAR LAMPUNG
}

\author{
Eti Hadiati \\ Fakultas Tarbiyah dan Keguruan UIN Raden Intan Lampung \\ eti.hadiati@radenintan.c.id
}

\begin{abstract}
Teachers' performance is one of the factors that is necessary to organize the excellent education and learning. Teachers' performance improvement effort is influenced by many factors, including discipline of work. The problem is discipline of work is not be a culture of school academic. The method used in this research was a quantitative method with survey approach and the location of this reserch is at MTs around Bandar Lampung with 82 persons of respondences chosen as the sample. Research result shows that discipline of work has a positive effect and significant to teachers' performance of the Mts around Bandar Lampung.
\end{abstract}

Keywords: Discipline of Work, Teacher's Performance 


\section{PENDAHULUAN}

UU No. 14 tahun 2005 tentang Guru dan Dosen menyebutkan bahwa guru adalah pendidik profesional dengan tugas utama mendidik, mengajar, membimbing, mengarahkan, melatih, menilai dan mengevaluasi peserta didik pada pendidikan anak usia dini jalur formal, pendidikan dasar dan pendidikan menengah. ${ }^{1}$ UU No. 14 tahun 2005 ini dilengkapi dengan Peraturan Pemerintah nomor 19 tahun 2005 tentang Standar Nasional Pendidikan yang menjelaskan bahwa seorang pendidik harus memiliki kompetensi sebagai agen pembelajaran berupa kompetensi pedagogik, kompetensi sosial, kompetensi kepribadian dan kompetensi professional. Ia juga dilengkapi Peraturan Menteri Pendidikan Nasional Nomor 16 tahun 2007 tentang standar kualifikasi dan kompetensi pendidik/guru. Semua ini merupakan wujud nyata keseriusan pemerintah dalam meningkatkan mutu pendidikan di Indonesia. Semua upaya tersebut perlu didukung dan ditindaklanjuti oleh semua pihak yang terkait agar tujuan pendidikan di atas dapat terwujud.

Supaya tujuan pendidikan tersebut dapat terwujud, maka perlu peningkatan kinerja guru; karena guru merupakan komponen yang paling berpengaruh terhadap terciptanya proses dan hasil pendidikan yang berkualitas. Guru sebagai tenaga pendidik merupakan pemimpin pendidikan dalam unit yang lebih kecil yaitu di kelas. Oleh karena itu, perannya sangat vital dalam menentukan keberhasilan proses pembelajaran di kelas.

Peran kepemimpinan pendidikan tersebut akan tercermin dari bagaimana guru melaksanakan peran dan tugasnya. Ini berarti bahwa kinerja guru merupakan faktor yang amat menentukan bagi mutu pembelajaran/pendidikan yang akan berimplikasi pada kualitas output pendidikan setelah menyelesaikan sekolah. Ini berarti, kinerja guru dalam merencanakan dan melaksanakan pembelajaran merupakan faktor utama dalam pencapaian tujuan pengajaran. Dalam hal ini, keterampilan penguasaan proses pembelajaran sangat erat kaitannya dengan tugas dan tanggung jawab guru sebagai pengajar dan pendidik.

Menurut Muhtar, "kinerja guru adalah seluruh aktivitas yang dilakukannya dalam mengemban amanat dan tanggung jawabnya dalam mendidik, mengajar dan membimbing, mengarahkan, dan memandu peserta didik dalam mencapai tingkat kedewasaan dan kematangannya".

Berdasarkan pendapat di atas, kinerja guru merupakan seluruh aktivitas atau kegiatan yang harus dilakukan oleh guru dalam mendidik

${ }^{1}$ Departemen Pendidikan Nasional Republik Indonesia, Undang-undang Republik Indonesia Nomor 14 Tahun 2005 tentang Guru dan Dosen (Jakarta: Depdiknas RI, 2006) Bab 2, Pasal 6.

${ }^{2}$ Muhtar, Desain Pembelajaran Pendidikan Agama Islam, (Jakarta: Misaka Galiza, 2003), h. 84 
peserta didiknya. Selain itu, ia juga bertugas mengajar dan membimbing serta mengarahkan peserta didik untuk menuju kedewasaan dan kematangan.

Dengan demikian, guru mempunyai tugas untuk membimbing, mengarahkan dan juga menjadi teladan yang baik bagi para peserta didiknya. Dengan setumpuk tugas serta tanggung jawab yang diembannya itu, guru harus mampu menunjukkan bahwa dia mampu menghasilkan kinerja yang baik demi terciptanya pendidikan yang bermutu. Seorang guru yang baik adalah guru yang mampu mewujudkan suasana pembelajaran yang menyenangkan dan membuat peserta didik merasa nyaman menuntut ilmu bersama gurunya.

Tak dapat dipungkiri, kehadiran guru dalam proses pembelajaran di sekolah masih tetap memegang peranan yang penting. Peran tersebut belum dapat diganti dan diambil alih oleh siapa pun. Hal ini disebabkan karena masih banyak unsur-unsur manusiawi yang tidak dapat diganti oleh unsur lain. Karena itu, mengingat guru adalah salah satu komponen sumber daya manusia yang secara manusiawi juga tidak terlepas dari kekurangan dan kelemahan dalam melaksanakan kinerjanya, kinerja guru juga ditentukan oleh sikap disiplin kerja setiap guru. Disiplin para guru di sekolah/madrasah merupakan salah satu faktor yang sangat mempengaruhi tercapainya tujuan pendidikan sebab disiplin kerja merupakan salah satu faktor yang dapat menentukan keberhasilan kinerja seseorang. Oleh karena itu, guru dituntut untuk mematuhi peraturan yang telah ditentukan oleh pihak sekolah karena hal itu akan berpengaruh terhadap kinerja seorang guru. Selain gurunya sendiri yang berusaha meningkatkan kualitas kerjanya, pihak sekolah juga harus berusaha mengupayakan pemberdayaan gurunya agar memiliki kinerja yang baik dan profesional dalam menjalankan tugasnya.

Menurut pendapat Siswanto, disiplin kerja adalah "sebagai sikap menghormati, menghargai, patuh dan taat terhadap peraturan-peraturan yang berlaku baik secara tertulis maupun tidak tertulis serta sanggup menjalankan dan tidak mengelak untuk menerima sanksi-sanksinya apabila seseorang melanggar tugas dan wewenang yang diberikan kepadanya". ${ }^{3}$

Pendapat di atas menjelaskan bahwa seorang guru harus siap mematuhi peraturan-peraturan yang telah ditentukan terlebih seorang guru yang sudah diangkat menjadi pegawai negeri sipil (PNS) sesuai dengan sumpah janji yang sudah diikrarkan. Dari uraian tersebut maka dapat dipahami bahwa ada beberapa faktor yang dapat mempengaruhi peningkatan kinerja guru salahsatu diantaranya adalah disiplin kerja. Meskipun masih banyak faktor lain yang juga turut mempengaruhi peningkatan kinerja guru,

${ }^{3}$ Siswanto Sastrohadiwiryo, Manajemen Tenaga Kerja Indonesia, (Jakarta: Bumi Aksara, 2003), h. 291 
namun penelitian ini hanya membahas secara mendalam pada faktor disiplin kerja guru tersebut.

Berdasarkan hasil pra-survey yang peneliti laksanakan pada madrasah-madrasah tsanawiyah se-Kota Bandar Lampung sebagai lokasi penelitian, maka sesuai data yang penulis peroleh dari Kemenag Kota Bandar Lampung diketahui bahwa terdapat 2 Madrasah Tsanawiyah Negeri dan 27 Madrasah Tsanawiyah swasta dengan jumlah guru seluruhnya berjumlah 453 orang guru yang bertugas mengajar di MTs se-Kota Bandar Lampung

Selanjutnya, berdasarkan hasil pra survey penulis melalui wawancara dengan beberapa guru tentang kedisiplinan guru dalam mengajar hal ini dapat dilihat dalam tabel di bawah ini :

\section{Tabel 1}

\section{Hasil Pra Survey tentang Disiplin Kerja Guru di MTs se- Kota Bandar Lampung}

\begin{tabular}{|l|l|c|c|c|c|}
\hline No & \multicolumn{1}{|c|}{ Uraian Kegiatan } & A & B & C & D \\
\hline 1 & Patuh dan taat terhadap aturan tata tertib madrasah & $\sqrt{ }$ & & & \\
\hline 2 & Bekerja sesuai prosedur/norma yang telah ditetapkan & & $\sqrt{ }$ & & \\
\hline 3 & $\begin{array}{l}\text { Tepat waktu sesuai jadwal yang disepakati dalam } \\
\text { menjalan tugas }\end{array}$ & $\sqrt{ }$ & & \\
\hline 4 & Menghindari sanksi atau hukuman & & $\sqrt{ }$ & & \\
\hline
\end{tabular}

Keterangan:
A. Selalu
B. Sering
C. Kadang-kadang
D. Tidak pernah

Berdasarkan data dari tabel di atas dapat disimpulkan bahwa disiplin kerja para guru sangat baik, terutama guru yang PNS dikarenakan adanya pinger print yang diwajibkan untuk datang setiap hari kerja bagi semua guru. Hal ini yang membuat para guru memiliki rasa tanggung jawab untuk menerapkan kedisiplinan. Namun demikian, kinerja guru masih belum maksimal seperti apa yang diharapkan.

Hal ini terbukti dari hasil pra-survei penulis tentang kinerja guru yang menunjukkan masih banyak kinerja guru yang belum memuaskan; baik mengenai kinerja dalam perencanaan pembelajaran, dalam kegiatan belajar mengajar yang kurang menerapkan pembelajaran yang aktif, inovatif, kreatif dan menyenangkan (PAIKEM), kurang inovatif dalam pembelajaran maupun dalam kegiatan evaluasi pembelajaran, maupun kinerja guru dalam hal pemanfaatan media pembelajaran. Dalam pelaksanaan pembelajaran, masih ada guru yang belum menerapkan strategi pembelajaran yang bervariasi; 
sehingga yang terjadi pembelajaran terasa membosankan bagi siswa dan kinerja yang dihasilkan guru pun belum optimal. ${ }^{4}$

Untuk lebih jelasnya, itu dapat dilihat hasil pra-survey penulis terhadap 30 orang guru tentang kinerja guru MTs se-Kota Bandar Lampung dalam tabel di bawah ini:

\section{Tabel 2}

\section{Data Hasil Pra Survey tentang Kinerja Guru} di MTs Kota Bandar Lampung

\begin{tabular}{|c|l|c|c|c|c|c|}
\hline NO & \multicolumn{1}{|c|}{ INDIKATOR } & A & B & C & D & JML \\
\hline A & $\begin{array}{l}\text { Menguasai silabus serta petunjuk } \\
\text { pelaksanaannya, }\end{array}$ & 2 & 12 & 9 & 7 & 30 \\
\hline B & Menyusun program pengajaran (RPP) & 8 & 12 & 6 & 4 & 30 \\
\hline C & Melaksanakan proses belajar mengajar, . & 7 & 12 & 7 & 4 & 30 \\
\hline D & Penguasaan materi yang akan diajarkan & 6 & 11 & 7 & 6 & 30 \\
\hline E & Pemberian tugas-tugas kepada peserta didik & 8 & 14 & 2 & 6 & 30 \\
\hline F & $\begin{array}{l}\text { Kemampuan mengelola kelas dan disiplin } \\
\text { lalam menjalankan tugasnya }\end{array}$ & 4 & 12 & 6 & 8 & 30 \\
\hline G & $\begin{array}{l}\text { Kemampuan melakukan penilaian dan } \\
\text { evaluasi hasil belajar }\end{array}$ & 2 & 13 & 8 & 7 & 30 \\
\hline
\end{tabular}

Keterangan:

$\mathrm{A}=$ Selalu

$\mathrm{B}=$ Sering

$\mathrm{C}=$ Kadang-kadang

$\mathrm{D}=$ Tidak Pernah

Berdasarkan data yang ada dalam tabel di atas, jelaslah masih ada permasalahan-permasalahan di MTs se-Kota Bandar Lampung yang berkaitan dengan kinerja guru. Permasalahan tersebut tidak terlepas dari faktor-faktor yang mempengaruhinya, di antaranya disiplin kerja, yang dapat mempengaruhi peningkatan kinerja guru secara optimal. Untuk itu, maka dipandang perlu untuk melakukan penelitian yang berkaitan dengan kinerja guru yang bertugas di MTs se-Kota Bandar Lampung dan faktor-faktor yang diduga memiliki pengaruh terhadap kinerja guru tersebut. Sehingga, hasil dari temuan penelitian dapat dijadikan bahan evaluasi dan pertimbangan bagi pengambil keputusan yang berkaitan dengan peningkatan kinerja guru di Madrasah Tsanawiyah di kota Bandar Lampung.

Berdasarkan uraian pada latar belakang masalah di atas dapat diidentifikasi beberapa masalah yang menyebabkan kinerja guru belum meningkat secara optimal, yaitu:

1. Sebagian besar para guru sudah mematuhi tata tertib di MTs akan tetapi kinerja guru masih belum optimal

\footnotetext{
${ }^{4}$ Hasil observasi awal kinerja guru MTs se Kota Bandar Lampung, januari 2017
} 
2. Sebagian besar guru sudah bekerja sesuai dengan prosedur atau norma yang telah ditetapkan akan tetapi masih ada guru yang kurang optimal kinerjanya

3. Dalam menjalankan tugas sebagian besar guru sudah tepat waktu sesuai dengan jadwal meskipun masih ada beberapa guru yang kurang kinerjanya.

Berdasarkan latar belakang dan identifikasi masalaha di atas maka dapat dirumuskan permasalahan penelitian ini sebagai berikut : Apakah disiplin kerja berpengaruh positif dan signifikan terhadap kinerja guru MTs se- Kota Bandar Lampung,.

Selanjutnya tujuan penelitian yang penulis rumuskan berdasarkan permasalahan yang telah dirumuskan yaitu untuk mengetahui pengaruh disiplin kerja terhadap kinerja guru MTs se-Kota Bandar Lampung.

Hadari Nawawi mengemukakan bahwa disiplin adalah usaha untuk mencegah terjadinya pelanggaran-pelanggaran terhadap suatu ketentuan yang disetujui bersama agar pemberian hukuman terhadap seseorang dihindari. ${ }^{5}$ Dari pendapat ini, dapat dipahami bahwa disiplin adalah suatu usaha yang dilakukan untuk menghindari adanya hukuman yaitu dengan mencegah diri dari terjadinya pelanggaran-pelanggaran terhadap suatu aturan yang telah ditentukan.

Menurut Hasan Langgulung disiplin adalah "melatih, mendidik dan mengatur. Artinya, dalam kata disiplin mengandung arti banyak dan dapat diterapkan dalam segala aspek kehidupan, termasuk bidang pendidikan."

Ravianto mengemukakan bahwa "disiplin adalah menaati atau taat pada ketentuan, peraturan, aturan main, kewajiban yang berkaitan dengan pekerjaan yang ditekuninya". ${ }^{7}$ Pendapat yang sama juga dikemukakan oleh A. Tabrani Rusyan dkk yang mengatakan bahwa disiplin adalah "suatu perbuatan yang mentaati, mematuhi tata tertib akan aturan, norma dan kaidah-kaidah yang berlaku baik di masyarakat maupun ditempat kerja." 8

Berdasarkan pendapat di atas jelaslah bahwa disiplin merupakan suatu kepatuhan atau ketaatan yang muncul dari dalam diri seseorang terhadap suatu aturan atau tata tertib yang telah ditentukan tanpa ada unsur keterpaksaan atau dengan kata lain suatu usaha pengendalian diri yang rasional terhadap sesuatu tanpa ada yang memaksanya. Jadi, dengan menerapkan disiplin merupakan proses pembelajaran atau latihan untuk

${ }^{5}$ Hadlari Nawawi , Pendidikan dalam Islam, (Surabaya: Al-Ikhlas, 1993), h. 128

${ }^{6}$ Hasan Langgulung, Manusia dan Pendidikan: Suatu Analisis Psikologis, Filsafat dan Pendidikan, (Jakarta: Pustaka Al-Husna, 1989), h. 401

${ }^{7}$ Ravianto J , Produktivitas dan Pengukuran, (Jakarta: Lembaga Sarana Informasi dan usaha, 1990), h. 134

${ }^{8}$ A. Tabrani dkk, Upaya meningkatkan Budaya Kinerja Guru Sekolah Dasar, Cet. Ke 2, (Jakarta: Inti Media Cipta Nusantara, 2001), h. 128 
meningkatkan kemampuan atau pengendalian diri terhadap sesuatu aturan yang sudah ditetapkan atau disepakati sebelumnya baik terhadap diri pribadi maupun terhadap masyarakat atau suatu organisasi yang mempunyai peraturan-peraturan yang telah ditetapkan.

Selain dari itu disiplin kerja seorang guru juga diatur dalam peraturan Pemerintah Republik Indonesia nomor 53 Tahun 2010 tentang disiplin Pegawai Negeri Sipil Pasal 1 menyatakan bahwa: disiplin pegawai negeri sipil adalah kesanggupan pegawai negeri sipil untuk mentaati kewajiban dan menghindari larangan yang ditentukan dalam peraturan perundang-undangan dan/atau peraturan kedinasan yang apabila tidak ditaati atau dilanggar dijatuhi hukuman disiplin.

Dari beberapa pendapat para ahli serta merujuk pada ketentuan Peraturan Pemerintah RI No 53 tahun 2010 tentang disiplin pegawai di atas, maka aspek-aspek disiplin kerja yang akan digunakan adalah sebagai berikut:

a. Patuh terhadap aturan tata tertib sekolah

b. Bekerja sesuai prosedur/norma yang telah ditetapkan oleh sekolah

c. Tepat waktu sesuai jadual yang disepakati

Berdasarkan beberapa pendapat diatas dapat disimpulkan bahwa disiplin kerja adalah sikap ketaatan, kepatuhan dan kesetiaan seseorang terhadap peraturan baik yang tertulis atau tidak tertulis yang tercermin dalam sikap perilaku maupun perbuatan dalam suatu organisasi. Disiplin adalah sikap yang terbentuk melalui proses dari serangkaian perilaku yang menunjukkan nilai-nilai individu ketaatan dan ketentuan berdasarkan acuan nilai moral individu untuk memperoleh perubahan tingkah laku yang mencakup perubahan berpikir, sikap, dan tindakan yang sesuai dengan peraturan dan ketentuan yang telah ditetapkan dalam belajar secara konsisten dan konsekuen dalam usaha untuk mendapatkan kepandaian ilmu.

Selanjutnya, menurut Soejono, disiplin kerja dipengaruhi oleh faktor yang sekaligus sebagai indikator dari disiplin kerja antara lain; 1) ketepatan waktu, 2) menggunakan peralatan kantor dengan baik, 3) tanggung jawab yang tinggi, 4) ketaatan terhadap aturan kantor, dan 5) pegawai memakai seragam kantor. ${ }^{9}$

Adapun indikator disiplin kerja adalah:

a. Patuh dan taat terhadap aturan tata tertib madrasah/sekolah

b. Bekerja sesuai prosedur/norma yang telah ditetapkan oleh madrasah/sekolah

\footnotetext{
${ }^{9}$ Soejono, Sistem dan Prosedur Kerja, Edisi Kelima (Jakarta: Bumi Aksara, 2000), h.
} 
c. Tepat waktu sesuai jadual yang disepakati dalam menjalankan tugas

d. Menghindari sanksi atau hukuman.

Siagian berpendapat bahwa kinerja merupakan suatu pencapaian pekerjaan tertentu yang akhirnya secara langsung dapat tercermin dari keluaran yang dihasilkan. ${ }^{10}$ Maksudnya, kinerja itu merupakan suatu prestasi kerja seseorang yang akan telihat dari hasilnya, berarti jika dia seorang guru maka prestasi kerjanya sebagai guru yang tercermin dari hasil pekerjaannya maka disebut dengan kinerja guru dan jika ia seorang pegawai atau karyawan suatu instansi yang memiliki prestasi kerja yang tercermin dari hasil kerjanya maka disebut dengan kinerja pegawai.

Anwar Prabu Mangkunegara mengatakan istilah kinerja guru berasal dari kata job performancelactual performance (prestasi kerja atau prestasi sesungguhnya yang dicapai oleh seseorang). Jadi menurut bahasa kinerja bisa diartikan sebagai prestasi yang nampak sebagai bentuk keberhasilan kerja pada diri seseorang. ${ }^{11}$ Keberhasilan kinerja juga ditentukan dengan pekerjaan serta kemampuan seseorang pada bidang tersebut. Keberhasilan kerja juga berkaitan dengan kepuasan kerja seseorang. Performance diterjemahkan menjadi kinerja yang berarti prestasi kerja atau pelaksanaan kerja atas pencapaian kerja atau hasil unjuk kerja atau penampilan kerja. ${ }^{12}$ Jadi kinerja adalah merupakan hasil kerja seseorang yang terlihat dari hasil prestasi nya.

Sementara itu, prestasi kerja atau penampilan kerja (performance) menurut Fattah adalah sebagai ungkapan kemampuan yang didasarkan oleh pengetahuan, sikap, keterampilan dan motivasi dalam menghasilkan sesuatu. ${ }^{13}$ Pendapat tersebut dipertegas lagi oleh Mulyasa bahwa kinerja adalah segala upaya yang dilakukan dalam mencapai tujuan. ${ }^{14}$

Membicarakan kinerja guru, hal ini tidak dapat dipisahkan dari faktorfaktor yang mempengaruhinya, yang akibatnya akan menyebabkan terhambatnya semua aktivitas pembelajaran jika tidak sesuai dengan apa yang dikehendaki. Menurut Depdiknas bahwa indikator kinerja guru yang kompeten antara lain adalah:

1. Kemampuan membuat perencanaan dan persiapan mengajar.

2. Penguasaan materi yang akan diajarkan kepada peserta didik 2002), h.327

10 Siagian P. Sondang, Kiat Meningkatkan Produktivitas Kerja (Jakarta: Rineka,

11 Anwar Prabu Mangkunegara, Manajemen Sumber Daya Manusia, (Bandung: Rosdakarya, 2000), h. 67

12 Lembaga Administrasi Negara RI, Budaya Organisasi dan Peningkatan Kinerja, (Jakarta: Pustaka Harapan , 1992), h. 3

13 Nanang Fattah, Ekonomi dan Pembiayaan Pendidikan, (Bandung: Remaja Rosdakarya, 2000), h. 19

${ }^{14}$ E. Mulyasa, Manajemen Berbasis Sekolah , (Bandung: Remaja Rosdakarya, 2003), h. 126 
3. Penguasaan metode dan strategi mengajar

4. Pemberian tugas-tugas kepada peserta didik

5. Kemampuan mengelola kelas

6. Kemampuan melakukan penilaian dan evaluasi. ${ }^{15}$

Berdasarkan indikator-indikator kinerja guru di atas maka sejumlah kemampuan tersebut harus dikuasai oleh guru guna meningkatkan kinerja guru ke arah yang lebih baik. Untuk itu maka perlu adanya upaya yang dapat dilakukan guru dalam meningkatkan kinerjanya adalah dengan beberapa cara, yaitu: (1) Melalui pendidikan formal, (2) melalui program pendidikan latihan, dan (3) pengembangan diri sendiri atas inisiatif sendiri berupaya memperoleh pengetahuan dan keterampilan. ${ }^{16}$

Melalui pendidikan maksudnya disini yaitu dengan meningkatkan latar belakang pendidikan sesuai dengan standar kualifikasi dan kompetensi seorang guru yaitu minimal harus sarjana strata satu (S1) dan memiliki kompetensi yang harus dikuasai oleh setiap guru yaitu kompetensi pedagogik, kompetensi profesional, kompetensi kepribadian dan kompetensi sosial. Upaya lain dapat ditingkatkan melalui pendidikan dan pelatihan yaitu seperti pelatihan-pelatihan yang sering diadakan dan upaya mengembangkan diri atas inisiatif sendiri yaitu seperti meningkatkan wawasan pengetahuan dan keterampilan dengan menambah sumber belajar dan lain sebagainya.

Berdasarkan uraian di atas maka jelaslah bahwa kegiatan-kegiatan yang berkaitan dengan kedisiplinan guru berpengaruh terhadap peningkatan kinerja guru dalam rangka mendidik dan mengajar siswa. Dengan demikian, diduga terdapat pengaruh disiplin kerja terhadap kinerja guru.

Adapun pola hubungan ini dapat dilihat dalam gambar di bawah ini :

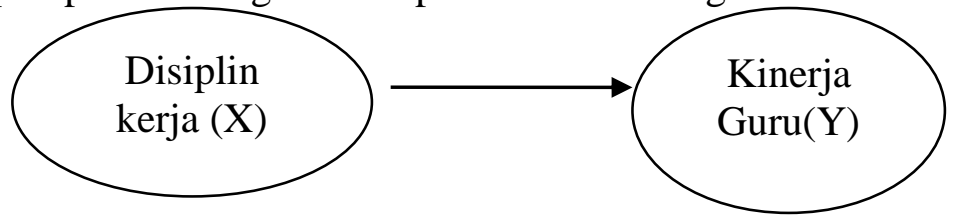

\section{Gambar 1. Hubungan variabel $X$ dengan $Y$}

Dengan demikian maka dalam penelitian ini penulis mengajukan hipotesis dengan rumusannya bahwa disiplin kerja berpengaruh positif dan signifikan terhadap kinerja guru MTs se- Kota Bandar Lampung.

Penelitian ini dapat digolongkan kedalam 3 (tiga) jenis atau tipe yaitu penelitian penjajakan (eksploratif), penelitian penjelasan (eksplanator), dan

\footnotetext{
${ }^{15}$ Depdiknas, Pembinaan Profesionalisme Tenaga Pengajar (Pengembangan Profesional Guru), (Jakarta: Dirjen Pendidikan Dasar dan Menengah, 2005), h. 14

${ }^{16}$ Sufyarma, Kapita Selekta Manajemen Pendidikan, (Bandung: Alfabeta, 2004), h. 37
} 
penelitian deskripsi. 17 Jenis penelitian yang akan digunakan dalam penelitian ini adalah penelitian deskriptif dengan pendekatan kuantitatif. Sedangkan objek dalam penelitian ini adalah tentang disiplin kerja dan kinerja guru MTs se- Kota Bandar Lampung. Untuk mendapatkan kejelasan dari masing-masing variabel penelitian tersebut maka perlu di jelaskan definisi operasionalnya agar dapat diketahui indikator-indikatornya yang dapat diukur sehingga dapat menggambarkan jenis data serta informasi yang diperlukan untuk menguji hipotesis.

Penelitian ini termasuk expost fakto yaitu penelitian yang dilakukan untuk mengetahui peristiwa yang telah terjadi dan kemudian menarik ke belakang, melalui data untuk menemukan faktor-faktor yang mendahului atau menemukan sebab-sebab. Dalam penelitian ini yang merupakan variabel bebas yaitu variabel disiplin kerja (X), dan ariabel terikatnya yaitu variabel kinerja guru $(\mathrm{Y})$.

Setiap variabel penelitian memiliki beberapa dimensi atau indikator yang merupakan penjelasan atas variabel tersebut, yang ditentukan atas dasar konsep teoritik dan hasil penelitian terdahulu, adapun definisi operasional dari masing-masing variabel ini adalah

a. Disiplin kerja (X) adalah merupakan suatu sikap ketaatan atau patuh yang dimiliki oleh seseorang secara sadar terhadap aturan, norma-norma atau kaidah-kaidah yang berlaku terhadap suatu aturan agar terhindar dari sanksi atau hukuman sehingga dapat tercapai tujuan yang dikehendaki. Indikator disiplin kerja adalah

1) Patuh dan taat terhadap aturan tata tertib madrasah/sekolah

2) Bekerja sesuai prosedur/norma yang telah ditetapkan oleh madrasah/sekolah

3) Tepat waktu sesuai jadual yang disepakati dalam menjalankan tugas

4) Menghindari sanksi atau hukuman

b. Kinerja guru (Y) didefinisikan sebagai suatu keberhasilan yang dimiliki oleh seorang guru sebagai pengajar dalam melaksanakan tugasnya baik dalam melaksanakan perencanaan, pelaksanaan maupun evaluasi pembelajaran. Indikator kinerja guru adalah :

1) Menguasai silabus serta petunjuk pelaksanaannya,

2) Menyusun program pengajaran (membuat perencanaan dan persiapan mengajar)

3) Melaksanakan proses belajar mengajar, (menerapkan variasi metode, media dan sumber belajar),

17 Singarimbun, Masri, \& E. Sofyan, Metode Penelitian Survey, Edisi Revisi, (Jakarta :LP3ES, 1999), h. 44. 
4) Penguasaan materi yang akan diajarkan dan berpikir sistematis

5) Pemberian tugas-tugas kepada peserta didik

6) Kemampuan mengelola kelas dan disiplin dalam menjalankan tugasnya

7) Kemampuan melakukan penilaian dan evaluasi hasil belajar.

Populasi dalam penelitian ini adalah seluruh guru MTs baik negeri maupun swasta se-Kota Bandar Lampung yang terdiri dari 29 MTs yang seluruhnya berjumlah 453 orang guru. Selanjutnya, dalam penetapan jumlah sampel penelitian ini digunakan rumus Taro Yaname dan Slovin. Menurut pendapat Riduwan dan Engkos, rumus ini digunakan jika populasi sudah diketahui. ${ }^{18}$ Dalam penelitian ini telah diketahui jumlah guru sebanyak 453 orang, baik guru di MTs negeri maupun swasta, maka jumlah sampel pada penelitian ini adalah 82 orang guru MTs se-Kota Bandar Lampung.

Dalam penelitian ini ada beberapa metode pengumpulan data yang penulis gunakan, metode tersebut adalah : Angket (Kuesioner), Menurut Koentjaraningrat, Kuesioner adalah " suatu daftar yang diberikan rangkai pertanyaan mengenai masalah atau bilangan yang akan diteliti". ${ }^{19}$ Dalam penelitian ini penulis menggunakan jenis angket /kuesioner langsung mengingat data yang ingin penulis peroleh yaitu berkaitan dengan data tentang disiplin kerja sebagai variabel $\mathrm{X}$ dan data yang berkaitan dengan kinerja guru yaitu variabel $\mathrm{Y}$. Untuk itu maka angket/kuesioner ini merupakan metode primer dalam penelitian tersebut.

Selanjutnya metode dokumentasi adalah alat pengumpul data yang digunakan untuk mencari, mengenal hal-hal atau variabel yang berupa catatan, transkrip buku, surat kabar, majalah, peraturan-peraturan, notulen rapat dan sebagainya. ${ }^{20}$ Dokumentasi digunakan untuk memperoleh datadata tentang profil sekolah, visi, misi, data guru. Data siswa, keadaan sarana dan prasarana serta foto atau video rekaman kegiatan pembelajaran dalam proses penelitian. Selanjutnya dokumentasi digunakan untuk memperoleh data tentang jumlah guru, latar belakang pendidikan guru dan lainnya yang juga turut menentukan dalam penelitian ini. Sedangkan untuk mendapatkan data pendukung maka alat pengumpul data yang digunakan adalah wawancara/intervieu yang akan peneliti gunakan untuk memperoleh data yang kurang lengkap dari hasil angket yang dibagikan.

${ }^{18}$ Riduwan dan Engkos Achmad Kuncoro. Cara Menggunakan dan Memaknai Path Analysis (Analisis Jalur), Edisi Revisi, Cetakan Ketiga.(Bandung: Alfabeta, 2011), h.49

${ }^{19}$ Koentjaraningrat, Metode-metode Penelitian masyarakat, (Jakarta :Gramedia, 1986), h.173

${ }^{20}$ Suharsimi Arikunto,Suharjono dan Supardi, Penelitian tindakan Kelas,, (Jakarta :Bumi Aksara, 2007) , h.158 
Sesuai dengan jenis penelitian yang digunakan adalah pendekatan kuantitatif, Maka untuk menganalisa data peneliti menggunakan cara statistik dengan menggunakan rumus korelasi product Moment angka kasar. Yang sebelum nya dilakukan uji validitas dan reliabilitas terlebih dahulu untuk menguji instrument mengingat kualitas pengumpulan data sangat ditentukan oleh kualitas instrument atau alat pengumpul data yang digunakan. Angket/kuesioner sebagai alat pengumpul data atau data dikumpulkan dengan menggunakan kuesioner yang dikembangkan oleh peneliti, meliputi instrumen pengukuran mengenai disiplin kerja dan kinerja guru. Keduanya menggunakan instrumen dengan skala likert. Data yang diperoleh dianalisis dengan teknik korelasi sederhana dan uji t.

Analisis akan dilakukan melalui langkah-langkah pengolahan sebagai berikut;

1. Data entry, yaitu memasukkan data kedalam buku kode data .

2. Coding , Pemberian kode pada data .

3. Data Analysis, yaitu menghitung, analisis dan interprestasi data .

4. Penulisan laporan sebagai hasil akhir pelitian .

Data akan dianalisis secara kuantitatif untuk menguji hipotesis yang telah tersusun sebelumnya yaitu dengan menggunakan teknik analisis statistik dengan uji korelasi Product Moment dan uji t untuk mengetahui pengaruh supervisi akademik terhadap kinerja guru.

\section{PEMBAHASAN}

Berdasarkan hasil analisis data terbukti bahwa disiplin guru mampu membawa pengaruh yang positif dan signifikan terhadap peningkatan kinerja guru. Pertama: berdasarkan analisis data dengan statistik deskriptif diketahui bahwa melalui perhitungan nilai tendency central, kecenderungan sebaran skor angket $\mathrm{X}$ ke $\mathrm{Y}$ berada pada rentang skor/nilai dalam kategori cukup. di mana skor nilai rata-rata hanya sebesar 66, median (skor tengah) sebesar 65, namun skor yang sering muncul (modus) adalah sebesar 75 .

Kemudian, skor/nilai simpangan baku (standar deviasi) sebesar 7,68, Skor ini menunjukkan keragaman antar responden cukup kecil, maksudnya responden yang memiliki skor rendah dan skor tinggi tidak jauh berbeda, atau maksudnya tidak terdapat perbedaan yang sangat menonjol antara responden yang berada pada skor pencilan terendah dan yang berada pada skor pencilan tertinggi sebab sebagaimana yang dikehendaki sebaran nilai memusat pada pencilan tertinggi. Hasil temuan ini dapat dengan mudah pula dibuktikan dengan mengamati nilai/skor minimum dan maksimum, serta grafik. Diketahui skor minimumnya sebesar 48 dan skor maksimum 81 dan kurva grafik yang terbentuk membentuk lonceng, sebab kumpulan data lebih berada di tengah. Ini menggambarkan sebaran skor yang berada pada pencilan nilai 
terendah ataupun yang berada pada pencilan nilai tertinggi sangat sedikit. Namun secara umum skor responden cenderung berada pada daerah pertengahan (nilai tengah).

Kemudian, untuk lebih memperkuat temuan ini dihitung juga seberapa besar persentase skor angket $\mathrm{X}$ ke $\mathrm{Y}$. Hasil penelitian tentang disiplin guru menunjukkan skor responden yang paling banyak/tinggi berkisar antara skor 59 - 72 dengan presentasenya mencapai $56 \%$. Ini menunjukkan nilai yang cukup. Kesimpulan singkatnya, dari perhitungan analisis data dengan statistik deskriptif tercermin skor responden secara keseluruhan menunjukkan bukti yang kuat bahwa kedisiplinan yang diterapkan guru selama ini termasuk faktor penyebab utama kinerja guru menjadi meningkat.

Kedua berdasarkan analisis data dengan statistik inferensial diketahui bahwa nilai regresi linear sederhana X terhadap Y sebesar sebesar 132.800 dengan nilai Sig. (2-tailed) sebesar 0,000. Nilai Sig. (2-tailed) ini lebih kecil dari $0,05(5 \%)$. Ini artinya hipotesis nol (Ho) ditolak dan hipotesis alternatif (Ha) diterima. Kesimpulannya adalah disiplin kerja berpengaruh positif dan signifikan terhadap kinerja guru. Ini menunjukkan bukti yang kuat juga bahwa kedisiplinan yang diterapkan guru selama ini termasuk faktor penyebab utama kinerja guru menjadi meningkat.

Lebih lanjut, guna lebih memperkuat temuan ini, dihitung juga seberapa besar persentase skor angket X ke Y melalui perhitungan koefisien determinasi (KD) atau R Square, diketahui nilai KD sebesar 0,624 (62,4 \%). Ini artinya besar pengaruh disiplin guru $(\mathrm{X})$ terhadap kinerja guru $(\mathrm{Y})$ sebesar $62,4 \%$ dan sisanya sebesar $37,6 \%$ dipengaruhi oleh variabel-variabel lain yang tidak diteliti dalam penelitian ini.

Dalam tinjauan teori, mengapa disiplin guru berpengaruh positif dan signifikan terhadap kinerja guru disebabkan disiplin timbul dari dalam jiwa guru sendiri. Adanya dorongan untuk mentaati tata tertib sekolah dan belajar disiplin sangat diperlukan karena disiplin melahirkan semangat menghargai waktu, bukan menyia-nyiakan waktu berlalu dalam kehampaan.

Terkait dengan itu, Cece Wijaya dan Tabrani Rusyan menyatakan bahwa disiplin adalah sesuatu yang terletak di dalam hati seseorang yang memberikan dorongan bagi orang yang bersangkutan untuk melakukan sesuatu atau tidak melakukan sesuatu sebagaimana telah ditetapkan oleh norma dan peraturan yang berlaku. Dalam keteraturan sikap atau keteraturan tindakan. Dengan demikian, maka jelaslah bahwa disiplin merupakan suatu kepatuhan atau ketaatan yang muncul dari dalam diri guru sendiri terhadap suatu aturan atau tata tertib yang telah ditentukan tanpa ada unsur keterpaksaan atau dengan kata lain suatu usaha pengendalian diri yang rasional terhadap sesuatu tanpa ada yang memaksanya. Jadi, dengan menerapkan disiplin merupakan proses pembelajaran atau latihan untuk 
meningkatkan kemampuan atau pengendalian diri terhadap sesuatu aturan yang sudah ditetapkan atau disepakati sebelumnya.

Berdasarkan dari uraian di atas maka jelaslah bahwa disiplin adalah merupakan suatu sikap ketaatan atau patuh yang dimiliki guru secara sadar terhadap aturan, norma-norma, atau kaidah-kaidah yang berlaku terhadap suatu aturan sekolah agar terhindar dari sanksi atau hukuman sehingga dapat tercapai tujuan pendidikan yang dikehendaki.

Pendidik atau guru sebagai pengajar memiliki sikap disiplin dikarenakan guru mempunyai tugas yang harus dipatuhi mengingat pekerjaan para guru itu berhadapan langsung dengan para siswa atau peserta didik yang apabila tidak disiplin maka para siswanya akan berkeliaran di luar kelas sehingga mengganggu kelas lainnya yang sedang belajar, karena mengajar itu memerlukan kegiatan yang teratur bagi seorang guru. disiplin timbul dari dalam jiwa guru sendiri. Adanya dorongan untuk mentaati tata tertib sekolah dan belajar selalu berdisiplin dalam mengerjakan apapun. Berdisiplin artinya menghargai waktu, tidak menyia-nyiakan waktu tanpa membawa manfaat. Ini sesuai pendapat Cece Wijaya dan Tabrani Rusyan yang menyatakan bahwa disiplin adalah sesuatu yang terletak di dalam hati seseorang yang memberikan dorongan bagi orang yang bersangkutan untuk melakukan sesuatu atau tidak melakukan sesuatu sebagaimana telah ditetapkan oleh norma dan peraturan yang berlaku.

Dengan demikian, maka jelaslah bahwa disiplin merupakan suatu kepatuhan atau ketaatan yang muncul dari dalam diri guru sendiri terhadap suatu aturan atau tata tertib yang telah ditentukan tanpa ada unsur keterpaksaan atau dengan kata lain suatu usaha pengendalian diri yang rasional terhadap sesuatu tanpa ada yang memaksanya. Jadi, dengan menerapkan disiplin merupakan proses pembelajaran atau latihan untuk meningkatkan kemampuan atau pengendalian diri terhadap sesuatu aturan yang sudah ditetapkan atau disepakati sebelumnya.

Berdasarkan dari uraian ini maka jelaslah bahwa disiplin adalah merupakan suatu sikap ketaatan atau patuh yang dimiliki guru secara sadar terhadap aturan, norma-norma, atau kaidah-kaidah yang berlaku terhadap suatu aturan sekolah agar terhindar dari sanksi atau hukuman sehingga dapat tercapai tujuan pendidikan yang dikehendaki. Selain itu pula, sebagai pendidik atau guru wajib memiliki sikap disiplin mengingat pekerjaan para guru itu berhadapan langsung dengan para siswa yang apabila tidak disiplin maka para siswanya juga akan mencontoh untuk tidak disiplin.

\section{SIMPULAN}

Berdasarkan hasil penyajian dan analisis data, maka sesuai dengan rumusan masalah yang diajukan dalam penelitian ini diperoleh kesimpulan bahwa Disiplin kerja berpengaruh positif dan signifikan terhadap kinerja 
guru MTs se- Kota Bandar Lampung, hal ini terbukti bahwa hasil perhitungan koefisien determinasi (KD) atau $\mathrm{R}$ Square, diketahui nilai KD sebesar 0,624 (62,4\%). artinya besar pengaruh disiplin guru (X) terhadap kinerja guru (Y) sebesar 62,4\% dan sisanya sebesar 37,6 \% yang dipengaruhi oleh variabel-variabel lain yang tidak diteliti dalam penelitian ini.

\section{REFERENSI}

Anwar Prabu Mangkunegara, Manajemen Sumber Daya Manusia, Bandung: Rosdakarya, 2000.

A. Tabrani dkk, Upaya meningkatkan Budaya Kinerja Guru Sekolah Dasar, Cet. Ke 2, Jakarta: Inti Media Cipta Nusantara, 2001.

Depdiknas, Pembinaan Profesionalisme Tenaga Pengajar Pengembangan Profesional Guru, Jakarta: Dirjen : Pendidikan Dasar dan Menengah, 2005.

E. Mulyasa, Manajemen Berbasis Sekolah, Bandung: Remaja Rosdakarya, 2003.

Hadlari Nawawi , Pendidikan dalam Islam, Surabaya: Al-Ikhlas, 1993.

Hasan Langgulung, Manusia dan Pendidikan: Suatu Analisis Psikologis, Filsafat dan Pendidikan, Jakarta: Pustaka Al-Husna, 1989.

Koentjaraningrat, Metode-metode Penelitian masyarakat, Jakarta :Gramedia, 1986.

Lembaga Administrasi Negara RI, Budaya Organisasi dan Peningkatan Kinerja, Jakarta: Pustaka Harapan , 1992.

Muhtar, Desain Pembelajaran Pendidikan Agama Islam, (Jakarta: Misaka Galiza, 2003.

Nanang Fattah, Ekonomi dan Pembiayaan Pendidikan, Bandung: Remaja Rosdakarya, 2000.

Ravianto J , Produktivitas dan Pengukuran, Jakarta: Lembaga Sarana Informasi dan usaha, 1990.

Riduwan dan Engkos Achmad Kuncoro. Cara Menggunakan dan Memaknai Path Analysis (Analisis Jalur), Edisi Revisi, Cetakan Ketiga. Bandung: Alfabeta, 2011.

Siagian P. Sondang, Kiat Meningkatkan Produktivitas Kerja Jakarta: Rineka, 2002.

Singarimbun, Masri, \& E. Sofyan, Metode Penelitian Survey, Edisi Revisi, Jakarta :LP3ES, 1999.

Siswanto Sastrohadiwiryo, Manajemen Tenaga Kerja Indonesia, Jakarta:

Bumi Aksara, 2003.

Soejono, Sistem dan Prosedur Kerja, Edisi Kelima, Jakarta: Bumi Aksara, 2000. 
Sufyarma, Kapita Selekta Manajemen Pendidikan, Bandung: Alfabeta, 2004. Sugiyono, Metode Penelitian Pendidikan Pendekatan Kuantitatif, Kualitatif dan $R \& D$, Bandung : Alfabeta, 2008.

Suharsimi Arikunto,Suharjono dan Supardi, Penelitian tindakan Kelas,, Jakarta : Bumi Aksara, 2007. 